http://dx.doi.org/10.11646/phytotaxa.127.1.6

\title{
Gato hyalinus gen. et sp. nov., an unusual araphid tube-dwelling diatom from Western Pacific and Caribbean islands
}

\author{
CHRISTOPHER S. LOBBAN ${ }^{1} \&$ J. NELSON NAVARRO ${ }^{2}$ \\ ${ }^{\prime}$ Division of Natural Sciences, University of Guam, Mangilao, GU 96923, USA, \\ Email: clobban@uguam.uog.edu (corresponding author) \\ ${ }^{2}$ Pontifical Catholic University of Puerto Rico, Ponce, PR 00717, USA; \\ Email:nnavarro@live.com
}

\begin{abstract}
A new species of tube-dwelling diatom, unusual in being araphid, is described from benthic coral reef habitats in Guam, Palau, Puerto Rico and Jamaica. Gato gen. nov. is heteropolar and heterovalvar, exhibits very fine striae delimiting a narrow and irregular sternum, and possesses a series of rimmed pores on each side of the foot pole. One valve of the frustule has a rimoportula at the foot pole, but both valves possess a rimoportula at the head pole. The generitype, $G$. hyalinus sp. nov. forms small, branched colonies. Individual cells are oval, slightly tapered along the apical axis, 30-40 $\mu \mathrm{m} \times 13-15 \mu \mathrm{m}$, with 60-70 striae in $10 \mu \mathrm{m}$. On the foot pole with a rimoportula the rimmed pores are connected to the sternum by diagonal striae; several additional rimmed pores interrupt transapical striae further up both valves. We compare valve structure of G. hyalinus with Florella portoricensis and F. pascuensis, which we report for the first time from the Marshall Islands, and to Licmophora spp. We find no taxa to which this genus is related, and can identify no structure potentially homologous to the series of rimmed pores among the diatoms.
\end{abstract}

Key words: araphid diatom, Bacillariophyceae, coral reefs, tube-dwelling diatom, rimmed pores, rimoportulae

\section{Introduction}

Tube-dwelling diatoms (i.e., those that live in mucilage tubes usually of their own making) occur in many marine benthic habitats, from underneath polar ice (Medlin 1990) to tropical reefs (Lobban \& Mann 1987, Navarro 1987). In many temperate regions they form macroscopic colonies that resemble brown seaweeds and can reach bloom populations (Cox 1975, 1981, Lobban 1983, 1989), but most tropical colonies are microscopic. Only Nitzschia martiana (C. Agardh 1827: 629) Van Heurck (1896: 406) is exceptionally seen with the naked eye (Lobban \& Mann 1987, Lobban \& Tsuda 2003), but is more commonly discovered with a microscope. The taxonomic diversity in marine tube-dwelling diatoms includes several species of Berkeleya Greville (1827: pl. 294) and Parlibellus Cox (1988: 19) (Naviculales: Berkeleyaceae) (Cox 1975, 1988, Mizuno 1979, Navarro 1987), several species of Navicula Sect. Lineatae (Naviculales: Naviculacae), several species of Nitzschia Hassall (1845: 435) (Bacillariales: Bacillariaceae) (Lobban 1984, 1985), and at least two species of Gyrosigma Hassall (1845: 435) (Naviculalaes: Pleurosigmataceae) (Smith 1856, Sterrenburg 1989, Jansson et al. 1994). In addition, Mastogloia cocconeiformis Grunow (1860: 578) (Mastogloiales: Mastogloiaceae) forms branched tubes with a single cell at the base of each branch (John 1993, Hein et al. 1993). Besides these tube formers, several Navicula and Nitzschia species cohabit tubes made by other species (Lobban 1984, Basson \& Sims 1998). All taxa mentioned above are biraphid, and many are motile within the tubes. However, we encountered an araphid species that forms very small, branched colonies and has an apparently hyaline valve face in LM. We describe this species in a new genus and compare it to some other araphid taxa from Guam, especially Licmophora C. Agardh (1827: 628) and two species of Florella J.N. Navarro (1982: 248). 


\title{
Methods
}

Diatom samples were collected by hand during scuba diving or snorkeling in Guam, Palau and the Marshall Islands (CSL), Puerto Rico and Jamaica (JNN). Live and acid-cleaned samples were observed in LM and SEM as described in our previous work on Puerto Rico and Guam (Navarro 1996; Lobban et al. 2010). Referenced specimens except the types are in the authors' collections.

Terminology: In this genus there are both labiate openings, i.e. rimoportulae, and non-labiate openings. To distinguish the latter, and to avoid the assumption that they are homologous to rimoportulae, we adopt the descriptive term "rimmed pore" (porus marginatus), which Round et al. (1990) used with reference to a small opening in the middle of some valves of Podocystis J.W. Bailey (1854: 11).

\section{New species and genus descriptions}

\author{
Division Bacillariophyta \\ Class Fragilariophycidae F.E. Round 1990 \\ Order incertae sedis \\ Family incertae sedis
}

Gato Lobban \& J.N. Navarro gen. nov.

Frustula heteropolara heterovalvaraque, subtiliter striata, sterno angusto irregulari. Striae porosae, uniseriatae, marginem valvarum attingentes. Rimoportula grandior ad polum basalem valvae unae, rimoportula parvior ad polos apicales ambo valvarum. Series pororum marginatorum secus marginem valvarum utrinque poli basalis.

Frustules heteropolar and heterovalvar, finely striated with narrow, irregular sternum. Striae porate, uniseriate, continuing to valve border. Larger rimoportula at foot pole of one valve, one smaller rimoportula at head pole of each valve. Row of rimmed pores along valve margin on each side of the foot pole.

\section{Type species:-Gato hyalinus Lobban \& J.N. Navarro}

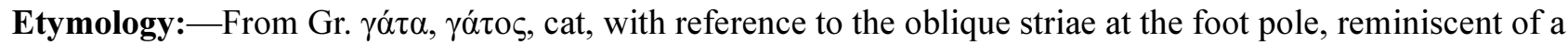
cat's whiskers.

Gato hyalinus Lobban \& J.N. Navarro sp. nov. (Figs 1-21)

Cellulae coloniales in tubis brevibus mucilaginis interdum ramosis. Chloroplasti numerosi lenticulares elongati. Valvae ovales parum angustatae versus basem, longitudine 30-40 $\mu \mathrm{m}$, latitudine 13-15 $\mu \mathrm{m}$. Striae transapicales tenuissimes, ca. 60-70 in $10 \mu \mathrm{m}$, paralleles praeter e extremo apicali sterni radians et prope polum basalem obliquaras. Rimoportula poli basalis in palla valvarum; rimoportula poli apicalis ad vel ultra extremum apicali sterni, prope pallam. Pori marginati non solum 3-5 in quoque lato poli basalis, in exemplum valvae rimoportula basali ferens una cum paribus striarum obliquarum e unusquaque versus sternum extensarum, sed etiam aliquot irregulariter in striis transapicalis prope marginem positis.

Cells colonial in short, sometimes branched mucilage tubes. Plastids numerous, elongate lenticular. Valves oval, slightly tapered toward foot pole, length 30-40 $\mu \mathrm{m}$, width $13-15 \mu \mathrm{m}$. Transapical striae extremely fine, ca. $60-70$ in $10 \mu \mathrm{m}$, parallel except radiating from head pole of sternum, and oblique at foot pole. Foot pole rimoportula on valve margin; head pole rimoportulae at or beyond end of sternum, near edge of mantle. Rimmed pores 3-5 on each side of the foot pole, on valve with basal rimoportula associated with pairs of oblique striae extending from each toward the sternum, and several others irregularly placed on transapical striae near margin.

Type:-GUAM. Apra Harbor, GabGab reef, 13 $26^{\prime} 33.63 " \mathrm{~N}, 144^{\circ} 38^{\prime} 34.25^{\prime \prime}$ E, acid cleaned material of diatoms, epiphytic on algal turf in farmer fish territories, collected 20 June 2009, GU44Z-15, strewn on microscope slide and filtered onto Millipore ${ }^{\circledR}$ filter paper. (Specimen circled on microscope slide marked CAS \#223005, accession \#627383, holotype, designated here; SEM stub of collection GU44Z-15 [deposited as holotype of the bleakeleyoid diatom Perideraion decipiens Lobban in Lobban et al. (2011)], CAS \#627385, isotype, designated here). 
Etymology:-hyaline, with reference to the lack of structure visible in LM.

Additional specimens examined:-GUAM: Agana Boat Basin, epiphytic on algal turf just below low water line, 29 November 1988, GU26A; GabGab, Apra Harbor, epiphytic on algal turf in farmer fish territories, 3 August 2008, GU44O-F, 1 September 2008, GU44P-B, 28 March 2009, GU44W-10 and 10 May 2009, GU44Y-13; Pete's Reef, Facpi Pt., 7 September 2008, GU55A-C. PALAU. Toachel ra Ngel, Ulebsechel I., 13 April 2009, PW2009-40. PUERTO RICO: Caja de Muertos Island, 27 December 1985; Enrique Reef, 7 m deep epiphyte on the red alga Amphiroa sp., 8 April 1994, slide \#C94-6. JAMAICA: Sponge Gardens, St Ann, 27 m deep, 19 November 1995, slide \#A96-14.

Observations:-Colonies (Figs 1-4) are a few cells long, sometimes branched, each cell at the end of a section of tube, from which the next section arose off-center; Fig. 4 suggests at least a temporary septum within the tubes. In Fig. 1 there appear to be cohabitant naviculoids in the tubes; these have not been commonly observed. Gato hyalinus cells are broadly oval, slightly narrower at the basal end, apparently with many elongate-lenticular plastids (Figs 1-4), and the cells arranged in the colonies with the narrower pole toward the base. Frustules are also slightly tapered in girdle view (Fig. 4). In acid-cleaned valves in LM (Figs 5,6 ), the rimoportulae can be seen, and sometimes a faint sternum, but the striae are too fine to resolve and the valves appear hyaline.

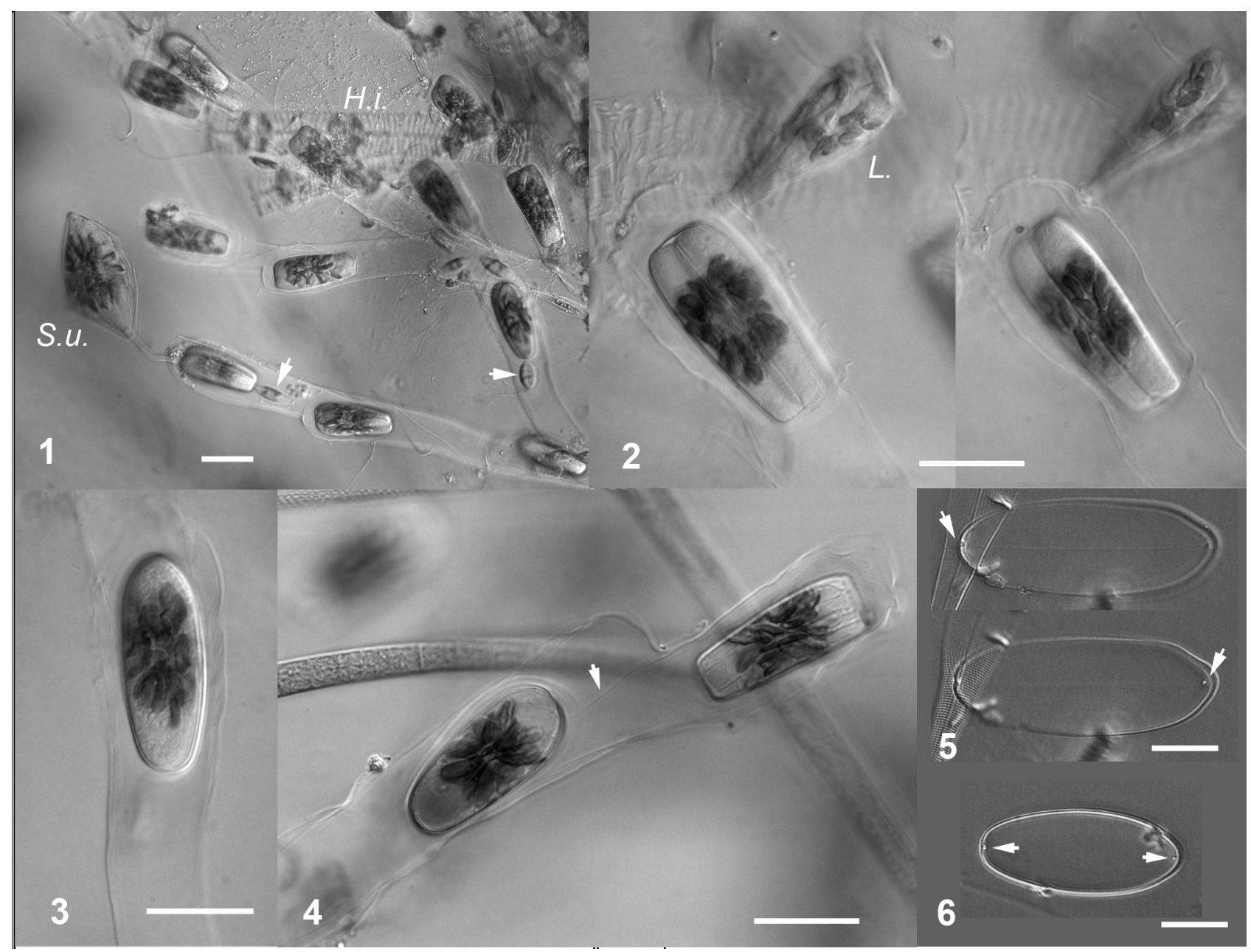

FIGURES 1-6: Gato hyalinus light microscopy. Figs 1-4: Live colonies and cells showing mucilage tubes and plastids. Fig. 1. Colony showing branching. A Striatella unipunctata cell (S.u.) has attached to the end of one tube and there appear to be naviculoid cells inside the tubes (some indicated by arrows). Top part of colony partially overlain by a ribbon of Hyalosira interrupta (H.i.) (GU44O-F). Fig. 2: Dividing cell in near-girdle view at apex of colony, at two focal planes. A Licmophora sp. cell (L.) is attached to the outside of the tube (GU44O-F). Fig. 3. Cell in valve view (GU44O-F). Fig. 4: Cells in valve and girdle view with some evidence of a septum (arrow) within the mucilage tube (GU44W-10). Figs 5-6: Acid cleaned valves in LM, oriented with basal pole to left. Fig. 5: Valve at two focal planes showing rimoportulae at both poles (arrows) and faint sternum (GU44Z-15). Fig. 6: Valve with two rimoportulae (arrows), sternum not visible (GU44Z-15). Scale bars: Figs $1-4=20 \mu \mathrm{m}$; Figs 5, $6=10 \mu \mathrm{m}$. 


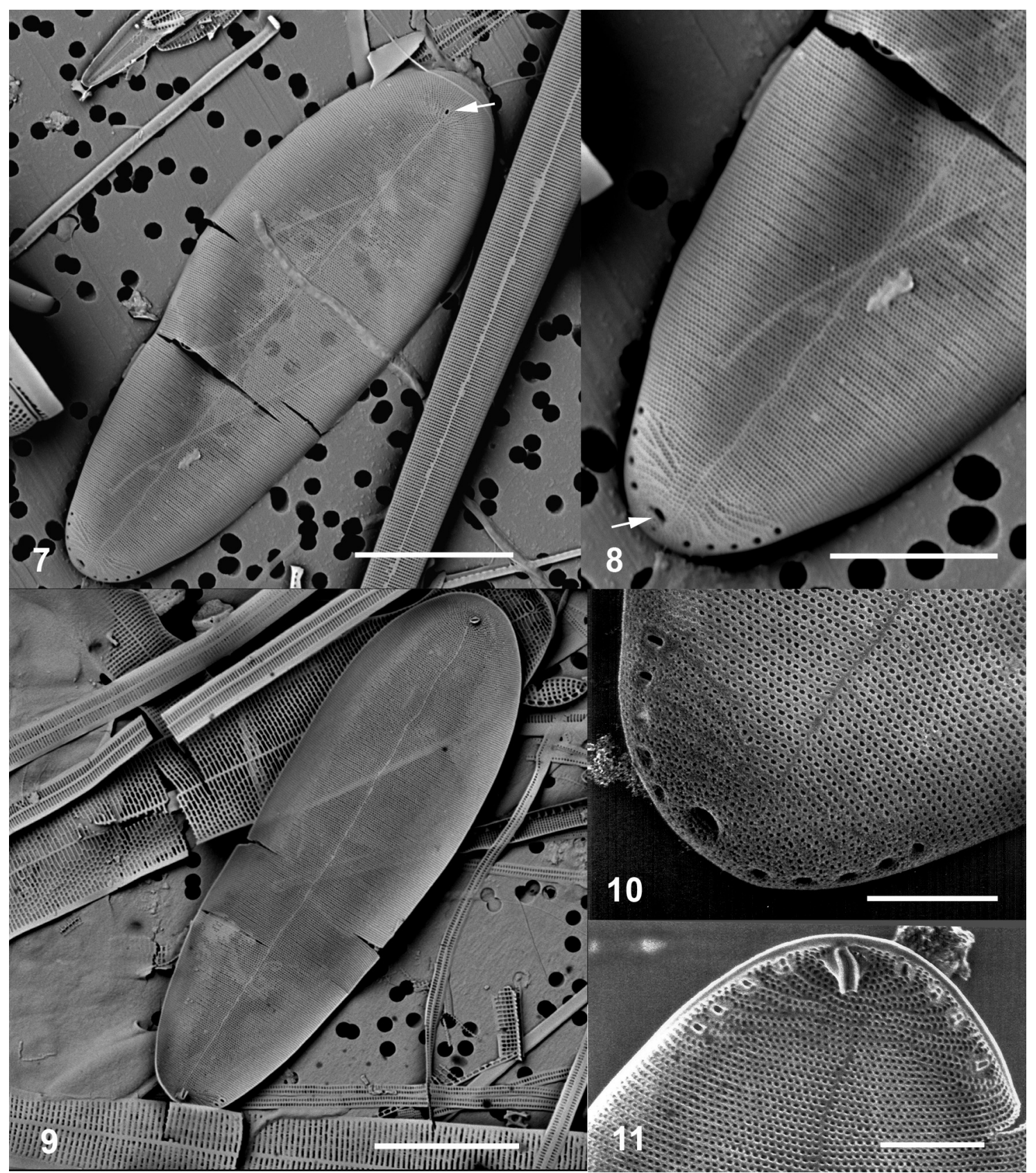

FIGURES 7-11: Gato hyalinus, SEM of valves with rimoportula at foot pole. Figs 7, 8: External view of valve and detail of basal pole showing external opening of rimoportula (arrow Fig. 8, also showing apical rimoportula opening, arrow in Fig. 7) and the two rows of rimmed pores with associated oblique striae ("cat's whiskers"). Fig. 9: Internal view of valve with rimoportulae at both poles (GU44P-B). Figs 10, 11: Details of basal pole with rimoportula in external and internal views (Puerto Rico sample). Scale bars: 7, $9=$ $10 \mu \mathrm{m} ; 8=5 \mu \mathrm{m} ; 10,11=2 \mu \mathrm{m}$.

In SEM, the valve surface is smooth, with rounded margins, striae 60-70 in $10 \mu \mathrm{m}$ consisting of uniseriate rows of simple circular pores (Fig. 19) that extend to the valve border (Figs 7, 8, 10, 11, 20). In places, the pattern could be described as quincunx (e.g., Fig. 13) but the spacing between pores in the striae is generally insufficiently consistent. There is a narrow, irregular break in the striae along the centerline, barely constituting a sternum (Figs 7-16,20). Striae are parallel except at the head pole, where they radiate from the end of the sternum (Figs 16, 20), and in association with the rimmed pores (Figs 8, 10). Both valves have a small rimoportula at the head pole near the valve apex, at or beyond the end of the sternum (Figs 9, 12, 13, 16, 20 ), but the two valves are different at the foot pole. There, only one valve of the frustule has a rimoportula and more strongly oblique striae - the "cat's whiskers" for which the genus is named (Figs 8, 10), the other valve lacks a rimoportula at the foot pole (Figs 12-20). Both foot poles have several large rimmed pores, i.e., 


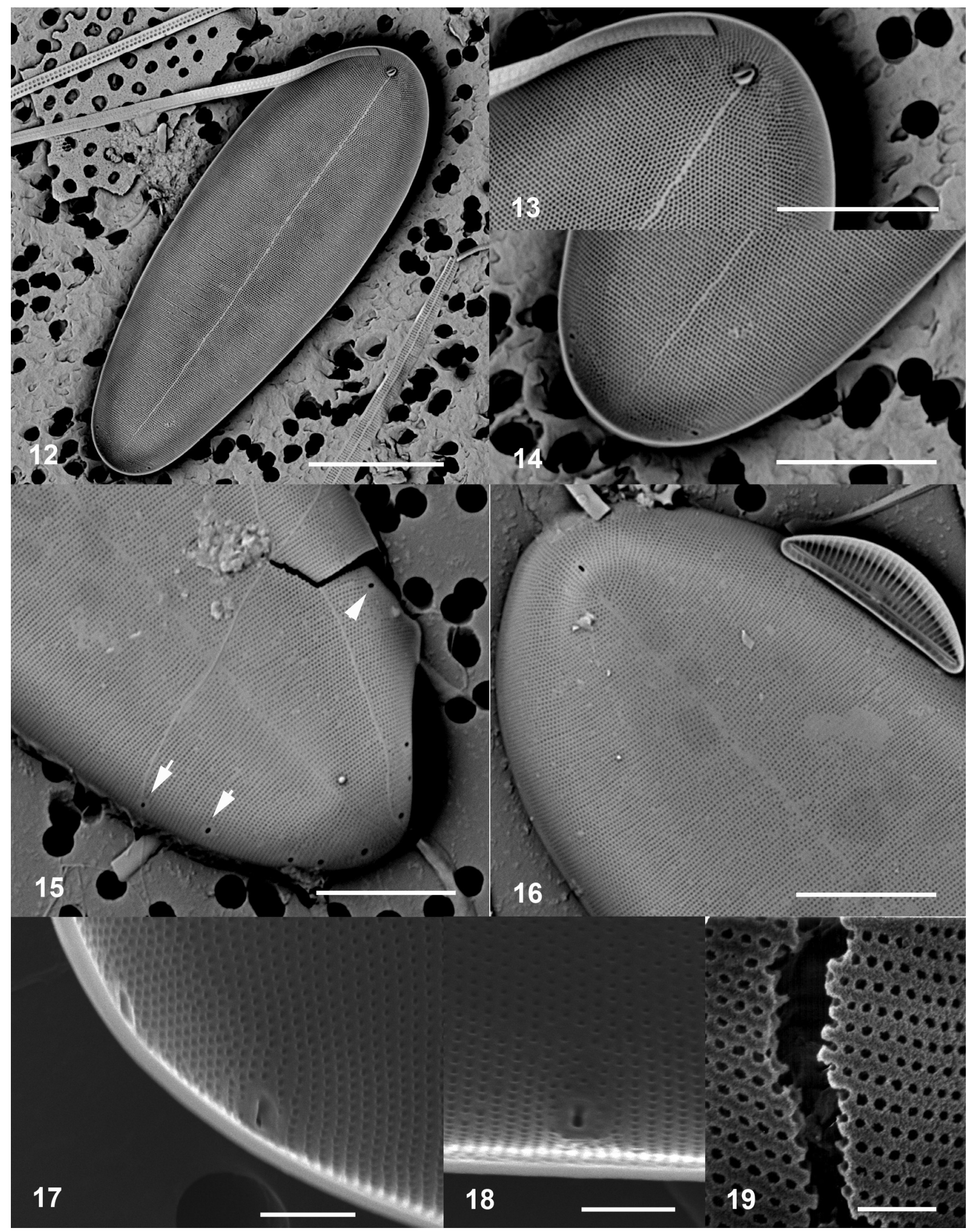

FIGURES 12-19: Gato hyalinus, SEM of valves without rimoportula at foot pole. Figs 12-14: Internal view of valve with rimoportula only at apical pole and detail of basal and apical poles (GU55A-C). Apical detail shows rimoportula at end of sternum. Basal detail shows irregular striae and rimmed pores. Figs 15, 16: External details of basal and apical poles of a valve with no basal rimoportula (GU44Z-15). Fig. 15. Basal pole shows three additional rimmed pores (arrows) interrupting transapical striae. Fig. 16: Apical pole shows rimoportula beyond the end of the sternum within the radiating striae. Figs 17, 18: Internal details of basal and apical poles of a valve with no basal rimoportula (GU44Z-15). Fig. 17: Detail of rimmed pores at the basal pole. Fig. 18: Detail of additional rimmed pore. Fig. 19: Detail of areolae along a fracture through the valve (Puerto Rico sample). Scale bars: Fig. $12=10$ $\mu \mathrm{m}$; Figs $13-16=5 \mu \mathrm{m}$; Figs $17,18=1 \mu \mathrm{m}$; Fig. $19=500 \mathrm{~nm}$. 


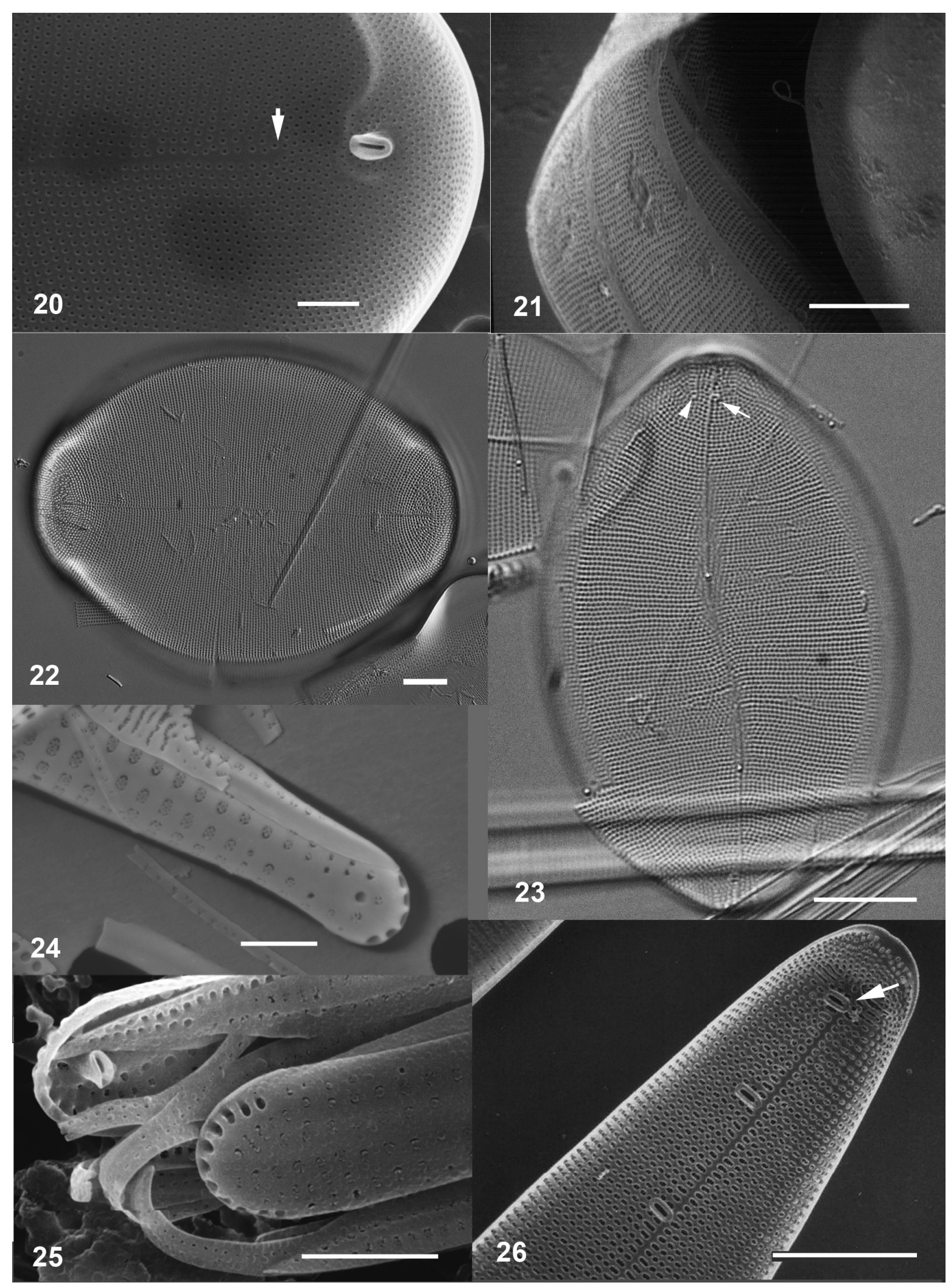

FIGURES 20-26: Figs 20, 21: Gato hyalinus, SEM. Fig. 20: Head pole showing end of sternum (arrow), radiating striae, and rimoportula (GU44Z-15). Fig. 21: Portion of girdle bands (internal aspect) (Puerto Rico sample). Fig. 22: Florella portoricensis, LM, acid cleaned valve (RMI-M1: 5 m deep, Mile 28, Laura, Majuro Atoll, Marshall Islands). Fig. 23: Florella pascuensis LM, acid cleaned valve, showing a rimoportula (arrow) and one of the rows of transapical slits (arrowhead) (RMI-J5: $1 \mathrm{~m}$ deep reef on Kabbenbock Islet, Jaluit Atoll, Marshall Islands). Figs 24-26: Licmophora spp., SEM. Fig. 24: Foot pole of Licmophora proboscidea?, external view showing areolae, rimoportula opening, and multiscissura with 5 slits (GU41D-A1). Fig. 25: Foot pole of Licmophora sp. showing internal and external details of multiscissura (11 slits) and rimoportula. Note absence of rimoportula on the valve in external view. (Palau specimen.) Fig. 26: Licmophora flabellata, internal view of apex showing an apical rimoportula at end of sternum (arrow), plus 2 additional rimoportulae along the sternum (Puerto Rico specimen). Scale bars: Fig. $22,23=10 \mu \mathrm{m}$; Fig. 24 $=5 \mu \mathrm{m}$; Figs $21,26=2 \mu \mathrm{m}$; Figs $20,25=1 \mu \mathrm{m}$. 
that have slightly thickened rims internally (Figs 7, 8, 10,11, 15, 17). There are two series of rimmed pores, typically $4-5$ on each side of the foot pole on the valve with a rimoportula; there are only 3 on those without a foot-pole rimoportula. In addition several irregularly placed pores occurred near the foot pole on both valves, interrupting 2 or more striae (Fig. 15, 18), but are not observed near the head pole. On valves with a basal rimoportula there are pairs of oblique striae extending from the sternum to the basal set of rimmed (Figs 7, 8, $10,11)$; these are not obvious on valves without a basal rimoportula, where only some irregularity in the striae was observed (Figs 14, 15, 17). We have little information on girdle bands, but they appear to be finely punctate (Fig. 21), similar to the valve surface.

Genera morphologically most similar to Gato are Florella and Licmophora. We do not suggest that either of these is related to Gato. Besides Navarro's $(1982,1996,2002)$ descriptions, we have observed Florella portoricensis Navarro (1982: 248, 258, emend Navarro 1996: 304) (Fig. 22) and Florella pascuensis Navarro (2002: 284) (Fig. 23) from the Republic of the Marshall Islands; this is the first confirmed report of these species from that country, and the first confirmed record of $F$. portoricensis from the Pacific Ocean. In addition Lobban et al. (2012) observed and cultured samples of $F$. pascuensis from Guam. The valves of Florella spp. are isopolar with parallel striae of cribrate areolae continuing unbroken to the valve border from an indistinct sternum; there are no pore fields. F. portoricensis has a series of rudimentary rimoportulae at each apex, indistinguishable from areolae except in internal SEM views, whereas $F$. pascuensis has two labiate rimoportulae, one at each end of the sternum, visible even in LM (Navarro 1996, 2002). F. pascuensis also has a unique pattern of slit-like areolae at each end.

Frustules of Licmophora spp., on the other hand, are heteropolar and heterovalvar. A series of $(5$ to $>30)$ simple slits at the foot pole is developed into a distinctive multiscissura (Figs 24, 25). The areolae (Fig. 24) are separated by virgae and viminae (Honeywill 1988). Although the rimoportulae of most Licmophora species are labiate rimoportulae (Fig. 25), in L. flabellata (Carmichael mscr. 1826, according to Agardh) C. Agardh (1831: 41, emend Sar \& Ferrario 1990: 404) the head pole rimoportula and the unique series of extra rimoportulae along the sternum lack labia (Fig. 26). These have been characterized by Sar \& Ferrario (1990) as "sessile rimoportulae" and are perhaps similar in structure (though not position) to the rimmed pores in Gato.

\section{Discussion}

Based on morphological criteria Gato does not appear close to any known genus of araphid diatoms. Licmophora species are an intriguing comparison because, like Gato, all are heteropolar, with distinctive structure at the basal pole; many are also heterovalvar with a basal rimoportula on only one valve. Some species of Licmophora have a rimoportula at the head pole on both valves, others have only one on the valve that lacks a foot-pole rimoportula. However, while the multiscissura might have a similar function to the series of basal rimmed pores in Gato, there is no evidence of homology, and there is no reason to suppose a relationship between Gato and Licmophora. The general structure of Florella is similar to Gato and unlike other araphids, but the symmetrical valves and the colony type are not like Gato. The most characteristic feature of Gato is the series of rimmed pores, for which we can find no parallel. Most araphids have a single rimoportula at one or both poles, but Sar \& Ferrario (1990) have shown that L. flabellata is an exception. The Florellaceae Navarro (1996: 301) was established on the basis of a single species (now it has two species), and its limits may need emending, but for the time being we leave Gato without familial or ordinal assignment.

The tube-dwelling habit of Gato is so far unique among araphids, but there is no reason to suppose a correlation between valve structure (e.g., the rimmed pores) and tube formation. While mucilage is often associated with apical pore fields (e.g., Grammatophora Ehrenberg (1840: 46), see Sato et al. 2008) or distinctive pores (e.g., partectal pores in some Mastogloia Thwaites in W. Smith (1856: 63), see Stephens \& Gibson 1979; Hein et al. 1993), no special structure is present in raphid tube-forming diatoms (Cox 1981; Lobban 1989). Similarly, while stalk secretion in Licmophora might be associated with the multiscissura, no 
evident structural features at the attachment pole are present in other taxa attached to stalks [e.g., Mastogloia inaqeualis Cleve (1895: 250) and M. cuneata (Meister 1937: 268) Simonsen (1990: 134)- Lobban et al. (2012), Climacosphenia Ehrenberg (1843: 401) spp., Ardissonea De Notaris in De Notaris \& Baglietto (1870: no. 334) spp.] or attached by a mucilage pad at one pole [e.g., Podocystis spp., Toxarium undulatum Bailey (1854: 15)]. Although diatom movement is most often associated with the raphe system, araphid diatoms can also move. For example Toxarium J.W. Bailey (1854:15) cells moved with one pole in contact with the substratum (Kooistra et al. 2003) but has no special structures to allow movement.

Gato hyalinus is easily overlooked as a girdle band in acid cleaned samples in LM but on the basis of our records of in the western Pacific and the Caribbean, we expect that it is widespread in the tropics.

\section{Acknowledgements}

CSL acknowledges NIGMS RISE funding for LM and SEM instruments on Guam and thanks Richard W. Jordan (Yamagata U.) and Matt Ashworth (U. Texas, Austin) for assistance with SEM, María Schefter for continuous encouragement and support, Isumech Ngirairkl for Fig. 25, and COMNAVMAR for access to the type locality at GabGab, Naval Station Guam. JNN thanks Integrated Microscope Resource at the University of Wisconsin at Madison for its help with the use of the SEM.

\section{References}

Agardh, C.A. (1827) Aufzählung einiger in den östreichischen Ländern gefundenen neuen Gattungen und Arten von Algen, nebst ihrer Diagnostik und beigefügten Bemerkungen. Flora 10: 625-646.

Agardh, C.A. (1831) Conspectus criticus Diatomacearum. Part 3. Lundae. Litteris Berlingianis, pp. 33-48.

Bailey, J.W. (1854) Notes on new species and localities of microscopical organisms. Smithsonian Contributions to Knowledge 7(3): 1-15, 1 pl.

Basson, P.W. \& Sims, P.A. (1998) A tube-dwelling diatom and its co-habitant from South Africa. Diatom Research 13: 395-401. http://dx.doi.org/10.1080/0269249x.1998.9705457

Boyer, C.S. (1927) Synopsis of North American Diatomaceae, supplement, part 2 -Naviculatae, Surirellatae. Proceedings of the Academy of Natural Sciences of Philadelphia 79: 229-583.

Cleve, P.T. (1895) Synopsis of the Naviculoid Diatoms, Part II. Kongliga Svenska-Vetenskaps Akademiens Handlingar 27(3): 1-219, 4 pls.

Cox, E.J. (1975) A reappraisal of the diatom genus Amphipleura Kütz. using light and electron microscopy. British Phycological Journal 10: 1-12. http://dx.doi.org/10.1080/00071617500650011

Cox, E.J. (1981) Mucilage tube morphology of three tube-dwelling diatoms and its diagnostic value. Journal of Phycology 17: 72-80. http://dx.doi.org/10.1111/j.1529-8817.1981.tb00821.x

Cox, E.J. (1988) Taxonomic studies on the diatom genus Navicula Bory. V. The establishment of Parlibellus gen. nov. for some members of Navicula sect. Microstigmaticae. Diatom Research 3: 9-38. http://dx.doi.org/10.1080/0269249x.1988.9705014

De Notaris, G. \& Baglietto, F. (1870) Erbario Crittogamico Italiano, Exsiccata. Ser. II, Fasc. VII. Genova. no. 301-350.

Ehrenberg, C.G. (1840) Über noch zahlreich jetzt lebende Thierarten der Kreidebildung und den Organismus der Polythalamien. Berlin 94 pp., 4 pls.

Greville, R.K. (1827) Scottish Cryptogamic Flora, or coloured figures and descriptions of cryptogamic plants, belonging chiefly to order Fungi. Volume 5, pls 241-30. Edinburgh and London, 360 pls. +1 colour plate.

Grunow, A. (1860) Über neue oder ungenügend gekannte Algen. Erste Folge, Diatomeen, Familie Naviculaceen. Verhandlungen der Kaiserlich-Königlichen Zoologisch-Botanischen Gesellschaft in Wein 10: 503-582, Tabs IIIVII.

Hassall, A.H. (1845) A history of the British Freshwater Algae (including descriptions of the Diatomaceae and Desmidiaceae) with upwards of one hundred Plates. Taylor, Walton, and Maberly, London. $462 \mathrm{pp}$.

Hein, M.K., Winsborough, B.M., Davis, J.S. \& Golubic, S. (1993) Extracellular structures produced by marine species of 
Mastogloia. Diatom Research 8: 73-88.

http://dx.doi.org/10.1080/0269249x.1993.9705240

Honeywill, C. (1998) A study of British Licmophora species and a discussion of its morphological features. Diatom Research 13: 221-271.

http://dx.doi.org/10.1080/0269249x.1998.9705450

Jansson, B., Sundbäck, K. \& Nilsson, C. (1994) An upright life-form of an epipelic motile diatom: Gyrosigma balticum. European Journal of Phycology 29: 11-15.

http://dx.doi.org/10.1080/09670269400650421

John, J. (1993) Morphology and ultrastructure of Mastogloia cocconeiformis (Bacillariophyta) from Shark Bay, Western Australia. Phycologia 32: 388-394.

http://dx.doi.org/10.2216/i0031-8884-30-6-556.1

Kooistra, W.H.C.F., De Stefano, M., Mann, D.G., Salma, N. \& Medlin, L.M. (2003) Phylogenetic position of Toxarium, a pennate-like lineage within centric diatoms (Bacillariophyceae). Journal of Phycology 39: 185-197. http://dx.doi.org/10.1046/j.1529-8817.2003.02083.x

Lobban, C.S. (1983) Colony and frustule morphology of three tube-dwelling diatoms from eastern Canada. Journal of Phycology 19: 281-289. http://dx.doi.org/10.1111/j.0022-3646.1983.00281.x

Lobban, C.S. (1984) Marine tube-dwelling diatoms of eastern Canada: descriptions, checklist, and illustrated key. Canadian Journal of Botany 62: 778-794.

http://dx.doi.org/10.1139/b84-114

Lobban, C.S. (1985) Marine tube-dwelling diatoms of the Pacific coast of North America. I. Berkeleya, Haslea, Nitzschia, and Navicula Sec. Microstigmaticae. Canadian Journal of Botany 63: 1779-1784. http://dx.doi.org/10.1139/b85-249

Lobban, C.S. (1989) Environmental factors, plant responses and colony growth in relation to tube-dwelling diatom blooms in the Bay of Fundy, Canada, with a review of the biology of tube-dwelling diatoms. Diatom Research 4: 89-109. http://dx.doi.org/10.1080/0269249x.1989.9705055

Lobban, C.S. \& Mann, D.G. (1987) The systematics of the tube-dwelling diatom Nitzschia martiana and Nitzschia section Spathulatae. Canadian Journal of Botany 65: 2396-2402. http://dx.doi.org/10.1139/b87-326

Lobban, C.S. \& Tsuda, R.T. (2003) Revised checklist of benthic marine macroalgae and seagrasses of Guam and Micronesia. Micronesica 35-36: 54-99.

Lobban, C.S., Ashworth, M.P. \& Theriot, E.C. (2010) Climaconeis species (Bacillariophyceae: Berkeleyaceae) from western Pacific islands, including C. petersonii sp. nov. and C. guamensis sp. nov., with emphasis on the plastids. European Journal of Phycology 45: 293-307. http://dx.doi.org/10.1080/09670262.2010.490924

Lobban, C.S., Ashworth, M.P., Arai, Y., Jordan, R.W. \& Theriot, E.C. (2011) Marine necklace-chain Fragilariaceae (Bacillariophyceae) from Guam, including descriptions of Koernerella and Perideraion, genera nova. Phycological Research 59: 175-193. http://dx.doi.org/10.1111/j.1440-1835.2011.00616.x

Lobban C.S., Schefter, M., Jordan, R.W., Arai, Y., Sasaki, A., Theriot, E.C., Ashworth, M., Ruck, E.C. \& Pennesi, C. (2012) Coral-reef diatoms (Bacillariophyta) from Guam: new records and preliminary checklist, with emphasis on epiphytic species from farmer-fish territories. Micronesica 43: 237-479.

Medlin, L.M. (1990) Berkeleya spp. from Antarctic waters, including Berkeleya adeliensis, sp. nov., a new tube dwelling diatom. Beihefte zur Nova Hedwigia 100: 77-89.

Meister, F. (1937) Seltene und neue Kieselalgen. II. Berichte der Schweizerischen Botanischen Gesellschaft 47:258-276; pls. $3-13$.

Mizuno, M. (1979) Taxonomic study on Berkeleya obtusa (Grev.) Grunow (Bacillariophyceae) from Hokkaido, Japan. Japanese Journal of Phycology (Sôrui) 27: 175-181.

Navarro, J.N. (1982) A survey of the marine diatoms of Puerto Rico. IV. Suborder Araphidinae: Families Diatomaceae and Protoraphidaceae. Botanica Marina 25: 247-263. http://dx.doi.org/10.1515/botm.1982.25.6.247

Navarro, J.N. (1987) Observations of a tube-dwelling diatom: Navicula hamulifera (Bacillariophyceae). Journal of Phycology 23: 164-170. http://dx.doi.org/10.1111/j.1529-8817.1987.tb04439.x

Navarro, J.N. (1996) New observations on the araphid diatom Florella portoricensis (Florellaceae fam. nov.). Diatom Research 11: 297-304. http://dx.doi.org/10.1080/0269249x.1996.9705386

Navarro, J.N. (2002) Florella pascuensis sp. nov., a new marine diatom species from Easter Island (Isla de Pascua), 
Chile. Diatom Research 17: 283-289.

http://dx.doi.org/10.1080/0269249x.2002.9705548

Round, F.E., Crawford, R.M. \& Mann, D.G. (1990) The Diatoms. Biology and morphology of the genera. Cambridge University Press, Cambridge. 747 pp.

Sar, E.A. \& Ferrario, M.E. (1990) Licmophora flabellata. Ultrastructure and taxonomy. 1. Implication. Diatom Research 5: 403-408.

http://dx.doi.org/10.1080/0269249x.1990.9705130

Sato, S., Mann, D.G., Nagumo, T., Tanaka, J., Tadano, T. \& Medlin, L.K. (2008) Auxospore fine structure and variation in modes of cell size changes in Grammatophora marina (Bacillariophyta). Phycologia 47: 12-27. http://dx.doi.org/10.2216/07-34.1

Simonsen, R. (1990) On some diatoms of the genus Mastogloia. Beihefte zur Nova Hedwigia 100: 121-142, 9 pls.

Smith, W.S. (1856) A Synopsis of the British Diatomaceae. Volume 2. John van Voorst, London. 107 pp + pls 32-60.

Sterrenburg, F.A.S. (1989) Studies on tube-dwelling Gyrosigma populations. Diatom Research 4: 143-150. http://dx.doi.org/10.1080/0269249x.1989.9705059

Stephens, F. C. \& Gibson, R.A. (1979) Observations of loculi and associated extracellular material in several Mastogloia (Bacillariophyceae) species. Revue Algologique, nouvelle serie, 14: 21-32.

Thwaites, G.H.K. (1848) Further observations on the Diatomaceae with descriptions of new genera and species. Annals and Magazine of Natural History, 2nd series, 1: 161-172, pls 11, 12. http://dx.doi.org/10.1080/03745485809496091

Van Heurck, H. (1896) A Treatise on the Diatomaceae. Translated by W.E. Baxter. William Wesley \& Son, London. 558 pp., 35 pls. 